\title{
Fear Not...!* \\ Turkish Nationalism and the Six Arrows System - A State in Search of a Nation
}

\begin{abstract}
SisKA KATALIN**
Abstract. "Korkma - Fear not" starts the Turkish national anthem that was officially adopted on 12 March 1921. A framed version of the Turkish national anthem, the symbol of the nation, and in wider sense the historical Turkic symbols of kinship typically occupy the wall above the blackboard in the classrooms of Turkish schools, accompanied by a Turkish flag, a photograph of the country's founding father Atatürk, and a copy of Atatürk's famous inspirational speech to the nation's youth from the concluding remarks to his 20 October 1927 address to the Parliament. The concept of nationalism of Atatürk remained a universal and timeless constitutional reference in Turkey. In the first part of this paper, the nature of Turkish nationalism at the time of its emergence is examined, studying this state shaped nationalism in a comparative context. The second part focuses on the constellation of the Atatürk's nationalism in the symbiotic system of the six arrows: nationalism, laicism, populism, republicanism, etatism and revolutionism.
\end{abstract}

Keywords: comparative legal history, kemalism, nationalism, identity, citizenship, Republic of Turkey, Europe

\section{INTRODUCTION}

The still vivid nationalism in Turkey is rooted in Atatürk ideas and in his constitutional law and politics. The paper offers a short review of the history and of the nature of this Türkish nationalism in order to remind the reader to certain specificities. This might also help to understand the contemporary events.

"Korkma - Fear not" starts the Turkish national anthem that was officially adopted on 12 March 1921 and is about the Turkish flag. The white moon, the nation's stars and redscene symbolizes the blood spilled for the nation. Mehmet Akif Ersoy wrote the poem for a nationwide competition in 1921 before the full official dissolution of the Ottoman Empire by the Turkish National Movement(TNM) - an independent and self-organized militia force led by Mustafa Kemal Atatürk. The TNM waged a lengthy campaign for independence against both invading foreign powers and the Ottoman Court. The goal of the competition

* Istiklal Marşı (Independence March). The first two stanzas in Turkish: Korkma, sönmez bu şafaklarda yüzen al sancak; | Sönmeden yurdumun üstünde tüten en son ocak. | O benim milletimin yıldızıdır, parlayacak; | O benimdir, o benim milletimindir ancak. | Çatma, kurban olayım çehreni ey nazlı hilâl! | Kahraman ırkıma bir gül! Ne bu şiddet bu celâl? | Sana olmaz dökülen kanlarımız sonra helâl, | Hakkıdır, Hakk'a tapan, milletimin istiklâl! In English: Fear not; For the crimson banner that proudly ripples in this glorious dawn, shall not fade, | Before the last fiery hearth that is ablaze within my homeland is extinguished. | For that is the star of my people, and it will forever shine; | It is mine; and solely belongs to my valiant nation. | Frown not, I beseech you, oh thou coy crescent! | Smile upon my heroic nation! Why the anger, why the rage? | Our blood which we shed for you shall not be worthy otherwise; | For freedom is the absolute right of my God-worshipping nation! http://www. allaboutturkey.com/anthem.htm (14/02/16).

** Associate professor, University of Debrecen Faculty of Law, Department of Legal History. E-mail: siska.katalin@law.unideb.hu 
was to select an original composition suitable for a National March, intended to provide inspiration and pride for a new homeland that would be established once victory was achieved.

"What I expect from the entire people without exceptions, is complete submission to the orders of the government. ... The entire nation accepted the principles I published and it was clear that those who opposed the principles or even my person had no chance of being elected deputies by the nation." - says Atatürk in his famous inspirational speech to the nation's youth in his speech of the 20 October 1927 in the Parliament ${ }^{1}$ The guiding principles of republicanism, laicism, nationalism, popularism, revolutionism and statism, officially appeared for the first time in 1931, in the political program of the Republican People's Party (Cumhuriyet Halk bank Isi), the first Turkish political party founded by Atatürk in 1923. Their logo symbolically featured six arrows. The manisfestation and the concept of the nation are still strongly linked to these principles.

On 5th February 1937, this program was included as a constitutional amendment into the Turkish Constitution of 1924. The Article 2 Clause 1 states: "Turkey is republican, nationalist, attached to the people, interventionist, secular and revolutionary."2

The military coups both in 1960 and 1980 resulted in fundamental revisions of the Turkish Constitution. The 1961 Constitutional Law Article 2 states "The Turkish Republic is nationalistic, democratic, secular and social state governed by the rule of law, based on human rights, and the fundamental tenets set forth in the preamble." The Article 2 of the Preamble states: "With full dedication to the principle 'peace at home peace in the world' and with full dedication to the spirit of national independence and sovereignty and to the reforms of Atatürk." 3

In the 1982 Constitutional Law Article 1 and 2 of the Preamble states "This Constitution, which affirms the eternal existence of the Turkish Homeland and Nation and the indivisible integrity of the Grand Turkish State, is entrusted for safekeeping by the Turkish Nation to the patriotism and nationalism of its democracy-loving sons and daughters, is to be understood, interpreted and implemented by its ideas, beliefs and determination in deference and with absolute loyalty to its letter and spirit, in the direction of the concept of nationalism defined by Atatürk, the founder of the Republic of Turkey, the immortal leader and the unrivalled hero, and his reforms and principles;" 4 In the 1982 Constitution, Article 1 Clause 1 states "The Republic of Turkey is a democratic, secular and social state governed by the rule of law; bearing in mind the concepts of public peace, national solidarity and justice; respecting human rights; loyal to the nationalism of Atatürk, and based on the fundamental tenets set forth in the Preamble."5

Article 1 of the Preamble in the current Turkish Constitution states "affirming the eternal existence of the Turkish Motherland and Nation and the indivisible unity of the Sublime Turkish State, this Constitution, in line with the concept of nationalism introduced by the founder of the Republic of Turkey, Atatürk, the immortal leader and the unrivalled hero, and his reforms and principles."

\footnotetext{
1 Kemal (2007) 24.

2 http://genckaya.bilkent.edu.tr/1924constitution.pdf

3 http://www.anayasa.gen.tr/1961 constitution-text.pdf

${ }^{4} \mathrm{https}: / /$ www.constituteproject.org/constitution/Turkey_2002.pdf

${ }^{5} \mathrm{https}: / /$ www.constituteproject.org/constitution/Turkey_2002.pdf

${ }^{6} \mathrm{https} / / /$ global.tbmm.gov.tr/docs/constitution_en.pdf
} 
Every political system has a shared language of symbols, narratives and priorities through which legitimation are sought. This language is basic and schematic yet generates legitimate priorities and state objectives. This mechanism will be examined bellow primarily in the Turkish context but having in mind other similar European solutions as well.

\section{EUROPEAN ROOTS AND THE EARLY DEVELOPMENT OF MODERN TÜRKISH NATIONALISM}

The creation of the citizenship as a legal concept is a modern phenomenon that coincides with the formation of the nation-states. ${ }^{7}$ The occurence of various definitions of "us" and "them" was reflected in the formation of the concepts of "citizen" and "foreigner" but reached legislative levels in the aftermath the French Revolution. ${ }^{8}$

The definition of citizenship, nationalité was published in the first edition of the Dictionnaire de l'Académie Française ${ }^{9}$ and meant to belong to a certain state and being a member of a particular nation. The former is a status; the latter could be defined as a quality. The idea that citizens belong to a state was primarily a legal concept based on the person's status determined by the applicable law. Nationals belonging to the nation were part of an imagined political community that could be understood as embedded in a large cultural system. ${ }^{10}$ Political implications were much more important than the legal ones.

The first law concerning foreigners was The Aliens Act (1792) in England, which introduced the institution of immigration control in response to the French political refugee movement. The uncontrolled influx of foreigners aroused anxiety in the British government circles as they feared that Jacobin spies, agents disguised themselves as political refugees, will be present in the country. America and Switzerland, in fear of the Jacobins' infiltration, also introduced similar provisions to the Aliens Act. The "peasants to Frenchmen"11 phenomenon spread rapidly and in different ways around the world, penetrating all levels of the modern politics.

Rogers Brubaker sociologist compares the development of the German and French conceptions of nationhood and citizenship as "it is one thing to want to make all citizens of Utopia speak Utopian, and quite another to want to make all Utophiphones citizens of Utopia. Crudely puts the former represents the French and the latter is the German model of the nationhood." 12

The French concept of citizenship evolved as an assimilationist, ambitious and statecentered manner while the German conception acquired an organic, differentialist dissimilationist and Volk-centered character. The French nationhood evolved in a predominantly political way while the Germanic model became predominantly ethnocultural. The French concept emerged as a political ideology while the German model as an ethnocultural stereotype whereby German people consider themselves as distinct section within the surrounding population in ethnic and cultural sense. ${ }^{13}$ The components according to Brubaker have been closely integrated in France, where political unity has

\footnotetext{
7 Bosniak (2008) 9.

8 Plender (1988) 10-25.

9 Dictionnaire de l'Academic Française (1835) 692.

10 Anderson (1983) 50.

11 Weber (1976) 124.

12 Brubaker (1992) 8.

13 Greenfeld (1993) 89-91, 275-8.
} 
been understood as constitutive, cultural unity as expressive of nationhood. In the German tradition, in contrast, political and ethnocultural aspects have stood in tension with one another, serving as the basis for competing conceptions of nationhood. This conception is sharply opposed to the French conception and according to this view ethnocultural unity is constitutive, political unity expressive, of nationhood..$^{14}$

The French nationalism appeared at about the same time as the French nation state and its political and social unit was the result of the work of statesmen. German nationalism preceded the formation of the German nation state by half a century and the German Romantic tradition was laden with motifs of yearning for a national state. ${ }^{15}$

The distinctions between nationalism in France and Germany and the different conceptualizations of citizenship are indispensable in understanding Turkish nationalism as it embraces the characteristics of both types of nationalisms and hence has a paradoxical nature. The early years of the Turkish Republic rather the political characteristics but in the 1930s the ethnocultural characteristics were dominant in Turkey.

Accepting Anderson's view the concept of nationalism is not treated as an ideology rather as if it belonged with 'kinship'. According to Hobsbawm, nationalism is a principle which holds that the political and national unit should be congruent. A principle that "once is created became 'modular', capable of being transplanted, with varying degrees of selfconsciousness, to a great variety of social terrains, to merge and be merged with a correspondingly wide variety of political and ideological constellations." 16 Hobsbawm views the development of nations as "situated at the point of intersection of politics, technology and social transformation" and must be seen as such. He claims that nations have traditionally been understood as top-down constructions and argues that they must also be looked at from the bottom-up. Building on this idea, he highlights the importance of language. He places particular importance on the development of class consciousness which, in turn, led to the development of the mass politics which made nations possible. ${ }^{17}$

The first and most important motive of "fabrication"18 the Turkish nation, as a political plan, was to preserve the sovereignty and the territorial integrity of the state that was threatened by the autonomus efforts of the non-Turkish groups during the reign of Sultan Mahmut II. (1808-1837) ${ }^{19}$ and was created ${ }^{20}$ by those intellectuals who were interested in preservation the integrity and at the same time the westernization. These intellectuals were linked to the Young Turk movement in period of 1904-1913. ${ }^{21}$

The Movement was basically consisted of two significant groups. The liberal wing was led by Prince Sabaheddine and was consisted of top-class, well-educated, Westernized intellectuals and some religious groups. They hoped that the British force will return and in cooperation with the high-class bureaucrats they will govern the constitutional monarchy. ${ }^{22}$ The unifying, nationalist wing was led by Ahmed Riza, the Minister of Education. They also banded together to defend the constitutional monarchy but were opposed to any idea of

14 Brubaker (1992) 10.

15 Kadiouglu (1996).

16 Anderson (1983) 48.

17 Hobsbawn (1990) 46-80.

18 Gellner (1964) 169.

19 Heper, Sayari (2012) 15-26.

20 Gellner (1964) 169.

21 Bulac (2015) 204.

22 Kadioglu (2007) 171-91, 172-3. 
foreign intervention. Instead, they were filled with national aspirations. Unlike the Liberals, their members were from the middle classes, teachers, officials and military officers. The unifying nationalists almost ferociously propagated the revolution above all idea, which in their opinion should be executed by public officials. The "national" nationalists, who were sympathetic towards the views of the famous writer Ziya Gökalp, did not want to co-operate with any non-Turkish factor. ${ }^{23}$ After 1908, this wing found enthusiastic followers and strenghten its position in the Committee. ${ }^{24}$ Overall, the nationalists' victory over the liberals marked the beginning of the Turkish nationalism, which was largely based on the concept that the state should be protected and the nation must stand in the service of the Turkish state. In fact, the Turkish nationalism and national identity worked as a necessary public officer. $^{25}$

The second motive of the Turkish nationalism was the intention of westernization. In the 18th century, the reforms imitating western solutions affected the military organization and in 1839 , the main characteristics of the provincial administration, education, judicial system. Turkism and nationalism were latent elements at the beginning of the westernization movement. However, as the movement accepted the Ahmed Ağaoğlu's pan-turkism ideology, which basic pillar was the westernization, these aims was implemented through these thoughts. ${ }^{26}$

According to Ziya Gökalp, ${ }^{27}$ the searching for the balance between the Western materialism, based on the principles of the Enlightenment and the Eastern spirituality, civilization and local culture is a returning companion of the Turkish concept of nation. ${ }^{28}$ According to Niyazi Berkes, ${ }^{29}$ the two concepts (culture and civilization) in Gökalp's conception of nationalism, does not represent conflicting and exclusive entities instead two closely related and complementary features that provides the social reality. ${ }^{30}$

Referring to Gellner, the Turkish nationalism did not mean awakening its national consciousness. On the contrary, this was an implementation of a plan accomplished by the intellectuals, full of questions about identity dilemmas. It was a special mixture of cosmopolitan and local elements, result of the work of intellectuals who raised the necessity of the transformation of the age-old superstitions and irrational results of western folk religion and mixed the western results with the Eastern spirituality. ${ }^{31}$

\section{THE MANIFESTATION OF THE TRANSFORMATION}

The caliphate was abolished in 1924 and the unifying power of the Islam between different ethnic groups came to an end. ${ }^{32}$ A "secular transformation of fatality into continuity" 33 was required and the best suited solution was giving politican expression of looming out of an

23 Koroglu (2007) 92.

24 Hanuoglu (2010) 197.

25 Cagaptay (2006) 14-9.

26 Özavci (2015) 192-4.

27 Aktar (1996) 263-90.

28 Daglyer (2007) 53-7.

29 Berkes (1981) 23.

30 Kadioglu (2007) 171-91, 172-3.

31 Chatterjee (1993) 51.

32 Yegen (1996) 216-29.

33 Anderson (1983) 51. 
immemorial past. This perception was manifested by Mustafa Kemal Atatürk “in today’s Turkish national, political and social community we have patriots and citizens ... individuals of this nation, as members of the integrated unified Turkish community, have a common past, history, morality and law." ${ }^{34}$ Beside the immemorial past, the picture of the limitless future was sketched in the CHP's (Republican People's Party/Turkish: Cumhuriyet Halk Partisi) program stating the nation is a political and social community of citizens based on the future principle "one language, one culture and one idea" (tekdil, tekkültür, tekülkü). ${ }^{35}$ This concept later became the nation's motto of the Republic and played very significant role in the construction of Turkish citizenship. The secularism (laiklik) also played an important role in establishing the political and cultural basis of Turkish citizenship. ${ }^{36}$

During the single-party period, the CHP distinguished between citizenship (being a Turkish citizen) and nationality (Turkishness) and tied citizenship rights to nationality. The single party period did not only differentiate between Turkish citizenship and Turkishness but also, as the political scientist Mesut Yegen clearly states, what the Turkish state understood by Turkish citizenship, which was said to be less than Turkishness. ${ }^{37}$

The founders of the new republic aspired to create a homogeneous nation state whose citizens speak Turkish, and possess Turkish culture. Turkey, however, was multiethnic and to some extent, multi-religious. The Muslim majority of the country was hardly homogeneous as there were Kurds, Bosnians, Albanians, Circassians and Arabs, who spoke languages other than Turkish. Thus the central question during the single party period was how to unify the ethnically, culturally and linguistically diversified citizens of the Republic and create a homogeneous nation state.

The main issue of the CHP in this period was to "turkificate" the citizens with various ethnic and religious backgrounds. Within this program, the knowledge of the Turkish language was considered one of the most important criteria of the real Turkish citizenship. Those people who do not speak Turkish became second-class citizens. ${ }^{38}$

There were several spoken vernaculars because the population was not homogenous. Anderson states that the most important step in the formation of the national consciousness was changing the character of the language, to create a unifield language of communication that can gradually become common. ${ }^{39}$

One of the most significant national assimilation campaigns were the Turkish linguistic campaign series “Citizens speak Turkish!” (Vatandas, Türkçe Konus!) which was supported by the Turkish government and created in January 1928 in Istambul. This campaign was very effective and exploded into the public consciousness. The turkification movement started at the same time with series of political reforms which ordered the mandatory use of the Turkish language in minority schools, in offices and economic institutions. ${ }^{40}$

In February 1932, city community centers (Turkish Halkevleri) were founded in 14 Turkish cities to promote the republic and the main principles of Turkish nationalism. Their aims were to create the ideal Turkish citizens, the ideal Turkish voter of the CHP who followed the six arrows of nationalism, laicism, populism, republicanism, etatism and

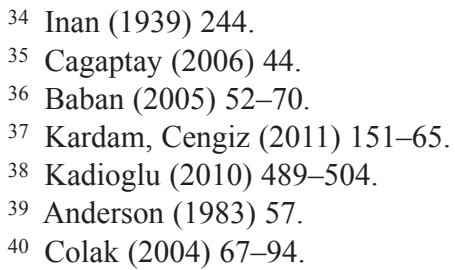


revolutionism. Hence the republican elite realized the citizenship in Turkey. ${ }^{41}$ The main target of the Ülkü (Great Ideals), the journal of the community centers, was to educate people within the theoretical framework of these concepts. ${ }^{42}$ Moreover Atatürk to heighten Turkish-Turkey's national consciousness at the expense of any wider Islamic identification, imposed compulsory Romanization. ${ }^{43}$

The concept of Turkish national identity was apparently shaped by state officials and was associated with trasformation the subjects of the Empire into the citizens of a nation state. This transformation in Turkey did not appear as a revolutionary social struggle by the masses, asking for their rights from those who did not grant it to them, but as a number of choices made by the ruling elite who tried to grant rights to the masses in order to increase social integration and to empower the state. However, when the state constituted Turkishness and Turk identity and forced its implementation in practice, it dominated the relationship between the state and the citizens.

\section{THE CONCEPT OF THE NATIONALISM IN THE SYSTEM OF THE SIX ARROWS}

"What I expect from the entire people without exceptions, is complete submission to the orders of the government. ... The entire nation accepted the principles I published and it was clear that those who opposed the principles or even my person had no chance of being elected deputies by the nation." 44

The content of the principles together with the six arrows (Alti Ok) is often summarized as Kemalism, (Turkish: Kemalizm, Atatürkçülük, Atatürkçü Düşünce) or Atatürkism The denomination was given after Mustafa Kemal Atatürk and practically was identical with the polical program of Atatürk's Republican People's Party (CHP).

The revolution and liberation was only the first step in the plan of Atatürk to create and continously maintain the national consciousness and increase the sense of pride of the national affiliation through his political statements. In a speech in 1923, he noted "No matter how great victories a nation achieved on the battlefield, victories bring longlasting results only by the efforts of the army of teachers." 45 Such statements revealed Atatürk's belief that the nation's struggle for the independence has not ended with its acquisition. Independence led to the foundation of the republic which paved the way for the modernization which was the ultimate aim of his revolutionism. ${ }^{46}$

In his famous speech on the 10th anniversary of the foundation of the Republic, he identified himself as a member of the great Turkish nation who is so proud of his citizens and his valuable army, because "the character of the Turkish nation is worthy and noble, the Turkish nation is industrious and the Turkish nation is intelligent. Because the Turkish nation has been successful in overcoming hardships through national unity and togetherness. And because the torch the Turkish nation holds in her hand and in her mind, while marching on the road of progress and civilization, is positive science. ${ }^{\prime 47}$

${ }^{41}$ Soyarik (2015) 43.

42 Ince (2012) 65.

43 Anderson (2010) 61.

44 Kemal (2007) 24.

45 Parla, Davison (2004) 119.

46 Parla, Davison (2004) 68-70.

4729 October 1933. http://www.ataturksociety.org/about-ataturk/ataturks-speech-at-the-10thanniversary-of-the-turkish-republic/ 
Turkishness was associated with intelligence, progress and bravery. The unit is vital for both the years of war and peacetime and essential because it ensures the progress and greatness. In contrast, the discord became the sign of stupidity and misfortune. His famous speech was concluded "ne Mutlu Türküm Diyene \How happy is the one who can say of himself I am a Turk." Turkishness became asssociated with happiness.

The secularism of Atatürk needs some interpretation in correlation with nationalism. Atatürk rejected the caliphate, which, according to him is nothing more than the object of mockery in the eyes of the civilized and cultured world. According to Andrew Mango, secularism resulted naturally from the rationalist philosophy of Atatürk. ${ }^{48}$ On the occasion of Nutuk, ${ }^{49}$ Mango noted that secularism was the least stressed principle from the six arrows and it was not necessary for Atatürk to emphasize the importance of secularism as in a modern state, it is only important when modernization takes place without it. However in his speeches, Atatürk encouraged Turks to clean up their emotions and knowledge "in the light of the true science" preventing that imaginative ideas of the Islamic tradition that can jeopardize the national survival. ${ }^{50}$

Secularism becomes an instrument for Atatürk to show the world that Turks are not a primitive nation who plunged on the level of prejudice and superstition. In this view, the caliphate is guilty of trying to sacrifice the Turkish nation for a simple whim and fantasy. ${ }^{51}$

According to Atatürk, the Republic was "the natural state of Turkey" and can be considered as progress". ${ }^{52}$ Therefore, Atatürk identifies republicanism and the unquenchable thirst for progress with the Turks. Secularism is depicted as a natural feature of the Republic which is necessary for the national survival and the development and similar to evolution "a nation must move with the time otherwise it will die."53 "In the eyes of the world our greatest strength and prestige is the new form and character of our regime" - he believed. ${ }^{54}$ The system which was linked to the national identity was meant to be a ticket to the civilized West.

Atatürk was a leader of a nation-founding nationalist liberation movement and it is not suprising that nationalism was one of the most powerful arrows in his program. Both the nationalism and the state of power usually includes spatiality. The state of power is territorially defined and the national identity itself is limited and sovereign. ${ }^{55}$ Therefore, the state seeks to determine and control their own territory where they have enough assistance and loyalty. The nationalism of Atatürk is also an ethnically connecting force that links the ethnically diverse Turkish nationals to the Türkish land. ${ }^{56}$ As a young first cadet in Macedonia and Syria, Mustafa Kemal saw that the Ottoman Empire would fall apart and could only be replaced by the Turkish nation-state.

The republicanism of Kemal was woven with nationalism. ${ }^{57}$ Atatürk combined the ancient blood ties with the citienship of the republic and transformed the citizenship into a

\footnotetext{
48 Mango (2002) 127.

49 Famous speech of Atatürk presented on 15-20th October 1927.

50 Aksit (1991) 45.

51 Heper (2016) 214.

52 Atatürk (2005) 14.

53 Atatürk (2005) 17.

54 Atatürk (2005) 19.

55 Anderson (1983) 49-50.

56 Herb (1999) 298.

57 Aksin (1999) 65.
} 
connecting power between the population of the land. Atatürk stated that both the Turks and the Republic are his creations and he believed that the two concepts are inherently linked to each other. The Turks carry the protection of the Republic in their blood. Individuals have to make efforts to protect what their ancestors died for. The one who does not feel loyalty towards the Republic of Turkey is not a real Turk.

Every citizen from childhood remember on the Speech on 20 October 1927 addressed to Young Turks because its text is carved on the wall of the most important public buildings, universities and the building of the Anitkabir (Mausoleum of Atatürk). The words of Atatürk, nationals must guard and protect the Republic and must be vigilant in respect both the external and internal enemies of Turkey, are deeply rooted in the national consciousness. Atatürk stated in 1937 that although the 11 nations became members of one family, the threat and danger of the national aspirations for independence still remains and consequently, the nation must remain vigilant. ${ }^{58}$

Atatürk with the fusion of nationalism and republicanism and with the statement that the Anatolian fatherland is the product of the nature of the Turks, defined and legitimized his own policies. After the collapse of the Ottoman Empire, the Ottoman / Islamic identity became the symbol of the defeat, humiliation, vulnerability and potential degradation; the secular Republic became the symbol of the collectivist and strongly anti-Ottoman-Islamic nationalism which guaranteed the safety and dignity of the Turkish nation. The Ottoman vulnerability was seen as the cause of the backwardness; Atatürk saw the republic as the first stage of the modernization. Atatürk saw the nation and himself as the natural expression and representative of the national will. ${ }^{59}$ As the political target was given (modernization) as well as the people lacked the political maturity to make appropriate decisions, Atatürk's populism according to Mango were the signs of reason and realism. ${ }^{60}$

The most influential arrow of the six was the revolutionism or reformism (the final step was modernization). This mainly referred to the transformation of the Ottoman Empire that took place along a non-violent revolution. The secular republic formed as a result of Atatürk's modernization movement. The reformism actually expressed the intention of Atatürk that the Turkish people stand by until the modernization of the Republic, the ultimate aim, is completed. ${ }^{61}$

The universal validity of the arrows was strengthened by building them into the constitution and maintaining throughout the constitutional amendments. ${ }^{62}$ The arrows were specific recommendations with pragmatic content with calid force to the Turkish political life. ${ }^{63}$

Nationalism, on its way from Atatürk's legacy to a timeless universal reference, needed one more untouchable ingredient - mysticism. The mystical bond between Atatürk, the nation and the republic was not only accepted but was an axiom in the Turkish textbooks and scientific life. According to this mysticism, the nation has to honour Atatürk, the "father of all Turks" with a monument of an honest father. Without him, Turkey would not be the same. Perhaps, Turkey would not be much smaller but would be a less peaceful country. ${ }^{64}$

\footnotetext{
58 Kinross (2001) 125.

59 Cagaptay (2006) 74.

60 Mango (2002) 77.

61 Mango (2002) 144.

62 Parla, Davison (2004) 9.

63 Takim, Yilmaz (2010) link 4., 4.

64 Mango (2002) 2-12.
} 
According to the message, he has led Turkey out of the "Eastern ghetto", ${ }^{65}$ created a new life and restored hope, energy and the self esteem of the Turkish people. He showed the way to independence but also to freedom. He saved his country from British imperialism, from being a client state, so the gratitude towards him is a quasi obligatory feeling. ${ }^{66}$

The Turkishness is not necessarily determined by race or religion but a measure of how a person can be connected to the concept of the thoughts and ideas that are identified as Turkish. The target of the Turkish nation is to protect the progress made so far and to promote the modernization. Other guidelines such as republicanism can not be a matter of choice. The links that Atatürk created amongst the people of Turkey effectively naturalized the whole republican project.

The fusion between the nation and the republic unified the population and created a quasi mystical aura around Atatürk and his charisma. Atatürk became an anthropomorphic nation, the symbol of revolutation, the saint of Turkey and the source and the guarantor of the national pride and security. On the anniversary of his death on $10^{\text {th }}$ November, an annual national holiday, students write letters to him asking for peace, health and prosperity. Some even complains to him and the letters often resemble prayers. ${ }^{67}$

\section{SUMMARY}

The concept of the nation in the proto-nationalism of Mustafa Kemal Atatürk was an imagined community based on the vison of common political life, language, territory, ancestors, historical affiliation and common moral. Religion was not the cohesive component of the nation. Common morals instead of a common religion were the focus. The concept of the general will was not typical of Atatürk policies as he held himself the embodiment of the national will, his nationalism was bordered by populism and formalism. In this context he insisted on that his decisions be materialized in legislative acts which were held as being in accordance with the will of the people. ${ }^{68}$

The ideas and principles of Mustafa Kemal Atatürk, the 6 paragraphs of the Program of the Republican People's Party (Cumhuriyet Halk bank Isi, or CHP) symbolized by six flying arrows was officially adopted in 1931, and in 1937 as a constitutional amendment was built in the Turkish Constitution of 1924 and with minor modifications remained in effect until 1961. These six principles were republicanism, interventionism, populism, laicism, nationalism, and revolutionism. This heritage is based on the pillars of collectivism, essentialism and teleology. The legitimacy of the kemalist principles consists of three layers. First of all the Turks' concept of citizenship, the national history and the fatherland linked as natural and essential elements. Secondly the republicanism is presented as a quasi ethnic trait of the Turkishness, an organic component of their natural identity.

Though Turkey's official secularism separates the secular from the divine and is opposed to the exploitation of religion only for political purposes, steps towards total secularization formed secularism to be a permanent state tool to control Islam, prevent the spread of imaginative ideas of the Islamic tradition which could, according to Atatürk, jeopardize the national survival. Nationalism was an instrument to show the world that Turks are not a primitive nation who plunged on the level of prejudice and

65 Lewis (2003) 293.

66 Lewis (2003) 294.

67 Volkan (2008) 344-5.

68 Feroz (2003). 
superstition. ${ }^{69}$ The Türkish nationalism made chnges on a state constitutional level.The modernizing reforms therefore were fundamentally different from all the earlier ones.

Since the legitimacy of the Türkish constitution derives primarily from the principles established by Atatürk, the print-language of Atatürkism became the unifield language of the communication of the members of the nationally imagined community. The concept of Turkish national identity strongly depends on the above described interpretation of legacy, still today. The children in Turkey are socialized in this language through the textbooks, language books, national narratives in the museums, they read this interpretation on the walls of the universities and on the national websites. In addition to the formulation of national identity this language is the language of the law, the language of the constitutional democracy, this forms a normative background of the legal system in Turkey. ${ }^{70}$ The Preamble of the current Turkish Constitution, in its part on the concept and the guiding principles, refers to Atatürk as "the founder of the Republic of Turkey, the immortal leader and the unrivalled hero."

In this paper I wished to emphasise in order to remind all of us, how these ideas developed through time and how they work and remain important and lively in contemporary Turkey. For understanding Turkey today, we have to keep in mind the nature of Atatürkism.

\section{LITERATURE}

Abadan Unat, N., Turks in Europe: From Guest Worker to Transnational Citizen (Berghahn Books 2011).

Aksit, B., 'Islamic Education in Turkey: Medrese Reform in Late Ottoman Times and Imam Hatip Schools in the Republic' in R Tapper (ed), Islam in Modern Turkey: Religion, Politics and Literature in a Secular State (I.B. Tauris 1991).

Aksin, S., 'Nature of the Kemalist Revolution' in D Shankland (ed), The Turkish Republic at SeventyFive Years: Progress -Development - Change (The Eothen Press 1999) 14-28.

Aktar, A., 'Economic Nationalism in Turkey: The Formative Years, 1912-1925' (1996) 1 Review of Social, Economic and Administrative Studies (Bogazici Journal) 263-90.

Anderson, B., Imagined Communities: Reflections on the Origin and Spread of Nationalism (Verso 1983).

Anderson, B., 'The Nation and the Origins of the National Consciousness' in M Guibernau and J Rex (eds), The Ethnicity Reader: Nationalism, Multiculturalism and Migration (Cambridge 2010) 58-97.

Arendt, H., The Origins of Totalitarianism (George Allen and Unwin 1967).

Atatürk, M. K., The Great Speech (Atatürk Arastirma Merkezi 2005).

Avedian, V., 'State Identity, Continuity, and Responsibility: The Ottoman Empire, the Republic of Turkey' (2012) 3 The European Journal of International Law 821-35.

Barker, R., Political Legitimacy and the State (Clarendon 1990).

Berkes, N., Turkish Nationalism and Western Civilization: Selected Essays of Ziya Gökalp (Greenwood Press 1981).

Bora, T., 'Nationalist Discourses in Turkey' (2003) 2-3 The South Atlantic Quarterly 433-51.

Brubaker, R., Citizenship and Nationhood in France and Germany (Cambridge 1992).

Bulac, A., Turkey's Democracy Saga: The Struggle Against Interventionist Politics (Blue Dome Press 2015).

Cagaptay S., Islam, Secularism, and Nationalism in Modern Turkey. Who is a Turk? (Routledge 2006).

69 Kinross (1993) 49.

70 Barker (1990) 57-61. 
Castles, St. and Davidson, A., Citizenship and Migration. Globalization and the Politics of Belonging (Routledge 2000).

Chatterjee, P., Nationalist Thought and the Colonial World: A Derivative Discourse (University of Minnesota Press 1993).

Ciddi, S., Kemalism in Turkish Politics: The Republican People's Party, Secularism and Nationalism (Routledge 2009).

Davison, R., Reform in the Ottoman Empire 1856-1876 (Princeton 1963).

Deingil, S., 'The Invention of Tradition as Public Image in the Late Ottoman Empire, 1808-1908' (1993) 1 Comparative Studies in Society and History 3-29.

Dinwiddy, J. R., The Use the Crown's Power of Deportation Under the Aliens Act, 1793-1826', (1968) 41/104 Historical Research (1 November 1968) 193-211.

Dzsihangir, F., A Török Köztársaság Fél Évszázada (Kossuth 1974).

Earle, E. M., 'The New Constitution of Turkey' (1925) 1 Political Science Quarterly 73-100.

Ergul, A., 'The Ottoman Identity: Turkish, Muslim or Rum?' (2012) 4 Middle Eastern Studies $629-45$.

Feroz, A., Turkey: The Quest for Identity (Oneworld 2003) 44-9.

Figlali, E. R., Atatürk and the Religion of Islam (Ankara University 1993).

Gellner, E., Nations and Nationalism (Cornell University 1983).

Gellner, E., Thought and Change (Chicago University 1964).

Greenfeld, L., Nationalism, Five Roads to Modernity (Harvard University Press 1993).

Heper, M., Islam, Secularism and Democracy in Turkey: The Legacy of Atatürk and the Challenges of Modernity (Tauris 2016).

Herb, G. H., Nested Identities: Nationalism, Territory, and Scale (Rowman \& Littlefield 1999).

Ince, B., Citizenship and Identity in Turkey: From Atatürk's Republic to the Present Day (Palgrave Macmillan 2012).

Kemal, G. M., A Speech Delivered By Ghazi Mustapha Kemal, President Of The Turkish Republic, October 1927 (Chandra Chakravarti 2007).

Kinross, P., Atatürk: The Rebirth of a Nation (Phoenix Press 2001).

Lewis, B., What Went Wrong? The Clash Between Islam and Modernity in the Middle East (Harper Perennial 2003).

Hanuoglu, S., A Brief History of the Late Ottoman Empire (Princeton 2010).

Hahner, P., 'A nemzeti állam és a nacionalizmus' (2011) 3-4 Rubicon 27-34.

Hekimoglu, M. M., Constitutional Developments of Turkey Since Ottoman Times To The Present State Of The Modern Turkish Republic (Grin 2010).

Heper, M., Ismet, I., The Making of a Turkish Statesman (Brill 1998).

Heper, M. and Sayari, S. (eds), The Routledge Handbook of Modern Turkey (Routledge 2012).

Hobsbawm, E., Nations and Nationalism since 1780: Programme, Myth, Reality (Cambridge University Press 1990).

Ince, B., Citizenship and Identity in Turkey (I.B. Tauris 2012).

Inan, A., 'Atatürk and the History Thesis' (1939) 3 Belleten 165-87.

Jung, D., Piccoli, W., Turkey at the Crossroads: Ottoman Legacies and a Greater Middle East (Zed Books 2001).

Kadiouglu, A., 'The Paradox of Turkish Nationalism and the Construction of Official Identity' (1996) 2 Middle Eastern Studies177-93.

Kadiouglu, A., 'An Oxymoron: The Origins of Civic-Republican Liberalism in Turkey' (2007) 2 Critical Middle Eastern Studies 171-90.

Kadiouglu, A., 'The Pathologies of Turkish Republican Laicism' (2010) 3-4 Philosophy and Social Criticism 489-504.

Kant, I., A gyakorlati ész kritikája (first published 1787, Budapest 1996).

Kardam, F., Cengiz, K., 'Republican Citizenship in Turkey: Historical Development, Perceptions and Practices' (2011) 1 Middle Eastern Studies 151-65.

Karpat, K., 'The Personality of Atatürk' (1985) 4 The American Historical Review 893-9.

Karpat, K., The Politicization of Islam: Reconstructing Identity, State, Faith, and Community in the Late Ottoman State (Oxford 2001).

Kedourie, S. (ed), Seventy-five Years of the Turkish Republic (Routledge 1999). 
Keyman, F., Icduygu, A. (eds), Citizenship in a Global World: European Questions and Turkish Experiences (Routledge 2013).

Kieser, H. L. (ed), Turkey beyond Nationalism (I.B. Taurus 2006).

Kili, S., 'Kemalism in Contemporary Turkey' (1980) 3 International Political Science Review 381-404.

Kinross, P., Atatürk. The Rebirth of a Nation (Weidenfeld \& Nicolson 2012).

Kinross, P., The Ottoman Centuries. The Rise and fall of the Turkish Empire (Perennial 2002).

Kirisci K.,'Migration and Turkey: The Dynamics of State, Society and Politics' in K Flett and S Faroqhi (eds), The Cambridge History of Turkey (Cambridge 2012) 122-47.

Koessler, M.,"Subject", "Citizen," "National," and "Permanent Allegiance" (1946) 56 Yale Law Journal 58-76.

Kohn, H., Prelude to Nation States: The French and the German Experience 1789-1815

(Van Nostrand 1967).

Kymlicka, W., Multicultural Citizenship: A Liberal Theory of Minority Rights (Oxford University Press 1995).

Kymlicka, W. and Wayne, N., 'Return of the Citizen: A Survey of Recent Work on Citizenship Theory' in R Beiner (ed), Theorizing Citizenship (State University of New York Press 1995) 35281.

Landau, J. (ed), Atatürk and the Modernization of Turkey (Brill 1984).

Leoussi, A. (ed), Encyclopaedia of Nationalism (Transaction Publishers 2001).

Mango, A., Atatürk: The Biography of the Founder of Modern Turkey (Overlook 2002).

Mardin, S., The Genesis of Young Ottoman Thought, A Study in the Modernization of Turkish Political Idea (Syracusa University Press 2000).

Meyer, J., Turks across the Empires. Marketing Muslim Identity in the Russian Ottoman Borderlands 1856-1914 (Oxford University Press 2014).

Nyers, P., 'Introduction: What's Left of Citizenship' (2004) 3 Routledge, Citizenship Studies 203-15.

Özavci, Ö., Intellectual Origins of the Republic. Ahmet A ̈gaoğlu and the Genealogy of Liberalism in Turkey (Brill 2015).

Özbudun, E., Genckaya, Ö. F., Democratization and the Politics of Constitution-Making in Turkey (CEU Press 2009).

Özbudun, E., Social Change and Political Participation in Turkey (Princeton University Press 2015).

Parla, T. and Davison, E., Corporatism Ideology on Kemalist Turkey Progress or Order? (Syracuse 2004).

Parolin, G. P., Citizenship in the Arab World.Kin, Religion and Nation-State (Amsterdam University Press 2007).

Pflanze, O., 'Bismarck and German Nationalism' (1955) 3 The American Historical Review 548-66.

Plender, R. (ed), International Migration Law (Brill 1988).

Reiss, H. (ed), Kant's Political Writings (Cambridge Universtiy Press 1991).

Schissler, H., Soysal, Y. N., The Nation Europe and the World. Textbooks and Curricula in Transition (Berghahn Books 2005).

Scruton, R., Anglia. Egy eltünő ideál (Typotex 2004).

Turner, B., The Citizenship and Capitalism: The Debate Over Reformism (Allen and Unwin 1986).

Weber, E., Peasants into Frenchmen: The Modernization of Rural France 1870-1914 (Stanford University Press 1976).

Wigen, E., 'The Education of Ottoman Man and the Practise of Orderliness' in M Pernau, H Jordheim (eds), Civilizing Emotions: Concepts in Nineteenth Century Asia and Europe (Oxford University Press 2015) 107-26.

Yegen, M., 'The Turkish State Discourse and the Exclusion of Kurdish Identity' (1996) 32 Middle Eastern Studies 216-29.

Volkan, V. D., 'On Kemal Atatürk's Psychoanalytic Biography' in B Tezcan and K Babir (eds), Identity Formation in the Ottoman World: A Volume of Essays in Honor of Norman Itzkowitz (Psychohistory Press 2008) 344-66.

Zürcher, E. J., The Young Turk Legacy and Nation Building from the Ottoman Empire to Atatürk's Turkey (I.B. Tauris 2010).

Zürcher, E. J., Turkey, a Modern History (I.B. Tauris 2004). 


\section{LINKS}

1. Akyol, T., "Greater Turkey" 2013. http://www.biyokulule.com/view_content.php?articleid=5823.

2. Kisteleki, K., Az állampolgárság fogalmának és jogiszabályozásának történeti fejlődésekoncepciók és alapmodellek Európában s Magyarországon. PhD értekezés. http://www.ajk.elte. hu/file/DI_Kisteleki_Karoly_dis.pdf.

3. Kurban, $\bar{D}$., 'Confronting Equality: The Need for Constitutional Protection of Minorities on Turkey's Path to the European Union' 2003. http://www.hyetert.com/prnyazi3.asp?s=\&Id=200\&S ayfa $=0 \&$ Dilld $=2 \&$ AltYazi.

4. Takim, A., Yilmaz, E., Economic policy during Ataturk's era in Turkey (1923-1938). 2010. http:// www.deu.edu.tr/userweb/sedef.akgungor/SOTE/Early\%20years.pdf

5. Whittaker, C., "La Généreuse Nation!" Britain and the French Emigration 1792-1802. 2015. https://www.academia.edu/2909048/_La_G\%C3\%A9n\%C3\%A9reuse_Nation_Britain_and_the_ French_Emigration_1792_1802. 